\title{
Temperature Compensated SAW Devices Using Bonded $\mathrm{LiTaO}_{3} / \mathrm{Sapphire}$
}

\author{
Michio Miura Non-member (FUJITSU LABORATORIES LTD., miura.michio@jp.fujitsu.com) \\ Shogo Inoue Non-member (FUJITSU LABORATORIES LTD., shogo@jp.fujitsu.com) \\ Jun Tsutsumi Non-member (FUJITSU LABORATORIES LTD., tsutsumi.jun@jp.fujitsu.com) \\ Takashi Matsuda Non-member (FUJITSU LABORATORIES LTD., matsuda.takashi@jp.fujitsu.com) \\ Masanori Ueda Non-member (FUJITSU LABORATORIES LTD., maueda@jp.fujitsu.com) \\ Yoshio Satoh Member (FUJITSU LABORATORIES LTD., satoh.yoshio@jp.fujitsu.com) \\ Osamu Ikata Non-member (Fujitsu Media Devices Limited, ikata.osamu@jp.fujitsu.com) \\ Yasuo Ebata Non-member (Fujitsu Media Devices Limited, ebata@jp.fujitsu.com)
}

Keywords : SAW, temperature compensate, $\mathrm{LiTaO}_{3}$, sapphire, direct bonding.

A novel temperature compensated SAW substrate was developed by using direct bonding techniques. Temperature compensating method using direct bonding techniques requires support substrate with small TEC (Thermal expansion coefficient) and large elastic coefficients. We evaluated the TEC and thermal stress of bonded $\mathrm{LiTaO}_{3} /$ glass and $\mathrm{LiTaO}_{3} /$ sapphire substrates by FEM (Finite element method) simulation. Fig. 1 shows the simulation results for the TECs of the bonded $\mathrm{LiTaO}_{3} /$ glass and $\mathrm{LiTaO}_{3} /$ sapphire substrates at the center of the $\mathrm{LiTaO}_{3}$ surface as a function of the $\mathrm{LiTaO}_{3}$ thickness. As shown in Fig. 1, the TEC of the $\mathrm{LiTaO}_{3} /$ sapphire substrate remains almost the same.

Thickness of the piezoelectric substrate also has large influence on spurious responses caused by bulk acoustic wave reflecting at the bonding interface. Fig. 2 shows the relationship between the amplitude of the spurious responses and the ratio of the $\mathrm{LiTaO}_{3}$ thickness to the SAW wavelength. The spurious responses are more strongly suppressed with increasing $\mathrm{LiTaO}_{3}$ thickness.

Fig. 3 shows the temperature characteristics of the resonant and anti-resonant frequencies of a one-port SAW resonator using a bonded $\mathrm{LiTaO}_{3} /$ sapphire substrate. $\mathrm{LiTaO}_{3}$ thickness of the bonded substrate was $37 \mu \mathrm{m}$, about 18 times of SAW wavelength. Sapphire thickness of the bonded substrate was $250 \mu \mathrm{m}$. The TCF was $-27 \mathrm{ppm} /{ }^{\circ} \mathrm{C}$ for the anti-resonant frequency and $-15 \mathrm{ppm} /{ }^{\circ} \mathrm{C}$ for the resonant frequency. The TCF for the anti-resonant frequency was about two-thirds of that for a resonator using a

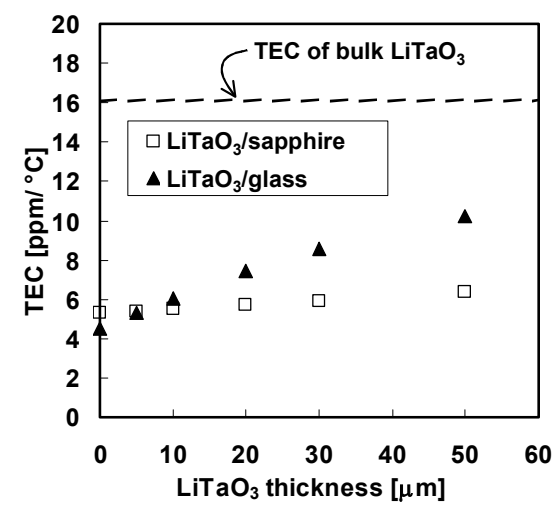

Fig. 1. FEM simulation results for the TECs of the bonded substrates at the center of the $\mathrm{LiTaO}_{3}$ surface conventional $\mathrm{LiTaO}_{3}$ substrate, while the TCF for the resonant frequency was about half of that with the conventional substrate.

Using bonded $\mathrm{LiTaO}_{3} /$ sapphire SAW substrate, US-PCS SAW duplexer with small temperature coefficient of frequency and good frequency characteristics was developed. Power durability of the duplexer using bonded $\mathrm{LiTaO}_{3} /$ sapphire SAW substrate was excellent because of high thermal conductivity of sapphire.

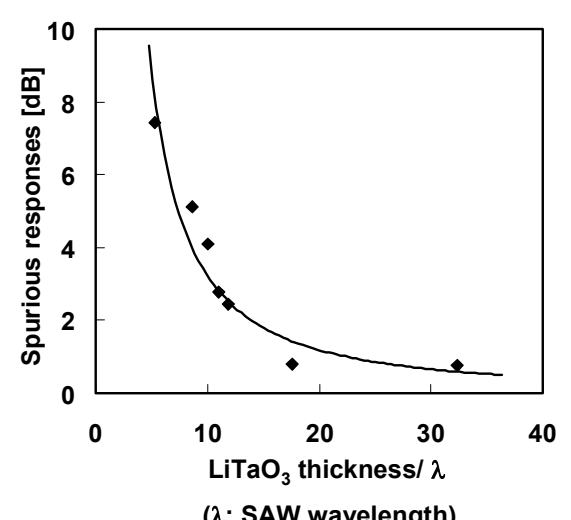

Fig. 2. Amplitude of the spurious responses as a function of the ratio of the $\mathrm{LiTaO}_{3}$ thickness to the SAW wavelength

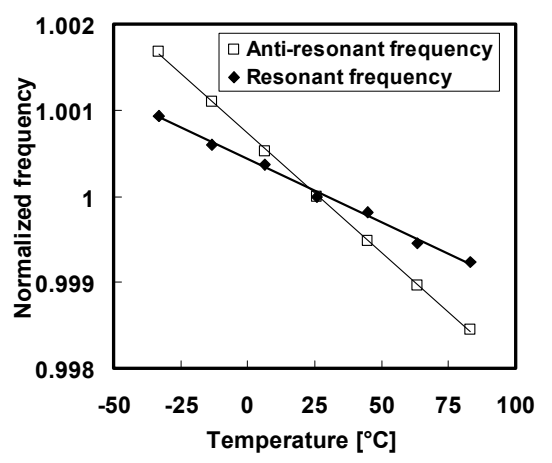

Fig. 3. Temperature characteristics of the resonant and anti-resonant frequencies of a one-port SAW resonator using a bonded $\mathrm{LiTaO}_{3} /$ sapphire substrate.surface 


\section{$\mathrm{LiTaO}_{3}$ /サファイア接合基板を用いた 温度特性改善 SAW デバイス}

\begin{tabular}{|c|c|c|c|c|}
\hline 非会員 & 三浦 & 道雄* & 非会員 & 井上 \\
\hline 非会員 & 堤 & 潤* & 非会員 & 松田 \\
\hline 会員 & 上田 & 政則* & 正 員 & 但 \\
\hline 全 & 形 & 理** & 非会員 & \\
\hline
\end{tabular}

\section{Temperature Compensated SAW Devices Using Bonded $\mathrm{LiTaO}_{3} / \mathrm{Sapphire}$}

Michio Miura*, Non-member, Shogo Inoue*, Non-member, Jun Tsutsumi*, Non-member, Takashi Matsuda*, Non-member, Masanori Ueda*, Non-member, Yoshio Satoh*, Member, Osamu Ikata**, Non-member, Yasuo Ebata**, Non-member

A novel temperature compensated SAW substrate was developed by using direct bonding techniques. This method has merits to keep the same coupling factor and propagation loss as the original piezoelectric substrate and need not strict control of substrate thickness. Temperature compensating method using direct bonding techniques requires support substrate with small thermal expansion coefficient and large elastic coefficients. Sapphire is one of the ideal materials for the support substrate. Thickness of the piezoelectric substrate has large influence on the temperature characteristics and spurious responses caused by reflection of bulk acoustic wave at the bonding interface. We found appropriate thickness of $\mathrm{LiTaO}_{3}$ with good temperature characteristics and no spurious responses. Using bonded $\mathrm{LiTaO}_{3} /$ sapphire SAW substrate, US-PCS SAW duplexer with small temperature coefficient of frequency and good frequency characteristics was developed. Power durability of the duplexer using bonded $\mathrm{LiTaO}_{3} /$ sapphire SAW substrate was excellent because of high thermal conductivity of sapphire.

キーワード : 弾性表面波, 温度特性, タンタル酸リチウム, サファイア, 直接接合

Keywords : SAW, temperature compensate, $\mathrm{LiTaO}_{3}$, sapphire, direct bonding

\section{1. まえがき}

近年，携帯電話に代表される携帯機器の小型化・高性能 化の進展により，弾性表面波（Surface Acoustic Wave，以下 SAW）フィルタなどの部品に対する小型化・高性能化の要 求も厳しくなっている。例えば, 従来は誘電体フィルタが 用いられていたアンテナデュープレクサを小型低背な SAW あるいは FBAR (Film Bulk Acoustic Resonator) を用いたもの で置き換えるなどの動きが広がっている。アンテナデュー プレクサなどのデバイスに高電力が印加される用途では, SAW フィルタに対する高性能化要求として, 一層の低ロ ス・高抑圧化に加え, 高耐電力化, 温度特性の改善などが

\footnotetext{
* (株)富士通研究所

T674-8555 兵庫県明石市大久保町西脇 64 FUJITSU LABORATORIES LTD.,

64 Nishiwaki, Ohkubo-cho, Akashi Hyogo 674-8555

** 富士通メディアデバイス(株)

干222-0033 神奈川県横浜市港北区新横浜 2-3-12

Fujitsu Media Devices Limited,

2-3-12 Shin-Yokohama, Kohoku-ku, Yokohama, Kanagawa 222-0033
}

求められる。北米の携帯電話規格の一つである PCS (Personal Communication Service) 方式では, $1.9 \mathrm{GHz}$ 帯でありながら 送信帯域 $(1.85 \mathrm{GHz}-1.91 \mathrm{GHz})$ と受信帯域 $(1.93 \mathrm{GHz}-1.99$ $\mathrm{GHz}$ )の周波数間隔がわずか $20 \mathrm{MHz}$ という厳しい仕様とな つており, 特に良好な温度特性が望まれる。従来の $\mathrm{LiTaO}_{3}$ 基板を用いた SAW フィルタでは, 使用温度範囲 $\left(-30{ }^{\circ} \mathrm{C}\right.$ から+85 $\left.{ }^{\circ} \mathrm{C}\right)$ における周波数変動量が約 $9 \mathrm{MHz}$ と周波数間 隔の約半分を占めてしまうため, 高度なフィルタ設計によ る急峻なフィルタ特性とばらつきの小さな量産プロセスが 必要であった(1)。一方, SAW フィルタの温度特性を改善す るために，多くの方法が提案されている。例えば， $\mathrm{LiTaO}_{3}$ 基板上に形成された IDT (Inter Digital Transducer) 上に厚く $\mathrm{SiO}_{2}$ 膜を堆積することによって温度特性を改善する方法(2)(3) が報告されている。但し，本方法では温度特性が改善でき ると同時に, 電気機械結合係数, IDT 電極での弾性波の反射 係数などのパラメータが変化する。本稿では, $\mathrm{LiTaO}_{3}$ とサ ファイアを接合した基板を用いることで，従来の $\mathrm{LiTaO}_{3}$ 基 
板を用いた場合とほぼ同じパラメータを持ちながら，同等 以上の周波数特性, 改善された温度特性, さらに高耐電力 化も実現できる SAW フィルタおよびそれを用いた US-PCS デュープレクサについて述べる。

\section{2. 接合基板を用いた温度特性改善}

〈2·1〉 支持基板材料の検討 $\quad \mathrm{LiTaO}_{3}$ など圧電基板の 裏面に支持基板を接合して温度特性を改善する方法につい ては，これまでも提案されている(4)。本方法では，圧電基板 より熱膨張係数が小さい材料からなる支持基板を圧電基板 裏面に接合することによって，圧電基板の温度変化による 伸縮を抑制して温度特性の改善を図る。そのため，支持基 板は小さな熱膨張係数および高いヤング率（弾性定数）を 持つことが必要である。さらに, IDT で発生するジュール熱 を効率よく排熱するために，熱伝導率が大きなことが望ま しい。表 1 に $\mathrm{LiTaO}_{3}$ と支持基板の候補となる材料の熱膨張 係数，ヤング率および熱伝導率を示す。ガラスは熱膨張係 数が小さいことから，支持基板として適しているようであ るが，ヤング率が小さいため $\mathrm{LiTaO}_{3}$ の伸縮を抑える効果が 小さいと考えられる。また，熱伝導率が小さいため IDT で 発生した熱を逃がすことができず，耐電力性が期待できな い。シリコンは小さい熱膨張係数とある程度大きさのヤン グ率，大きな熱伝導率を持つため有力な候補であるが，そ の導電性のためにフィルタのロスが増大寸る䀣念がある。 サファイアは熱膨張係数がガラス並みに小さく, かつ非常 に大きなヤング率を持つため $\mathrm{LiTaO}_{3}$ の伸縮を抑える能力が 高いと考えられる。さらに, 熱伝導率も大きく, IDT で発生 するジュール熱を効率よく排熱することができると考えら れる。

〈2·2〉 FEM シミュレーション 有限要素法 (FEM) を用いて, 接合基板の熱膨張係数と熱応力のシミュレーシ ヨンを行った。図 1 にシミュレーションに用いたモデルを 示す。チップサイズを $1 \times 0.6 \mathrm{~mm}$, 支持基板厚を $0.3 \mathrm{~mm}$ と した。図 2 に $\mathrm{LiTaO}_{3}$ 厚をパラメータとしたチップ中心での $\mathrm{LiTaO}_{3}$ 表面（SAW 伝搬方向 X 軸）の熱膨張係数のシミュレ ーション結果を示す。支持基板は表 1 に示したガラスとサ ファイアを用いた場合である。ガラスの材料定数は(4)の文 献で用いられている值を用いた。サファイアは R 面 (1102) 基板を用い， c 軸投影線に対し $45^{\circ}$ 方向を SAW 伝搬方向と 一致させている。支持基板がガラスの場合, $\mathrm{LiTaO}_{3}$ が薄い 場合は熱膨張係数が小さいが, $\mathrm{LiTaO}_{3}$ が厚くなるに従って 急速に $\mathrm{LiTaO}_{3}$ 自体の熱膨張係数に近づいていく。それに対 して，支持基板がサファイアの場合は， $\mathrm{LiTaO}_{3}$ が厚くなっ てもほぼ一定の熱膨張係数を維持している。この傾向の違 いはガラスとサファイアのヤング率に起因しており，ヤン グ率の大きなサファイアは $\mathrm{LiTaO}_{3}$ の膨張収縮を抑圧する能 力がより高いと考えられる。後述するが，フィルタ特性を 考慮すると $\mathrm{LiTaO}_{3}$ をある程度厚くする必要があるため，支 持基板としてはサファイアが望ましい。

〈2·3〉 スプリアスレスポンスの抑制接合基板上で

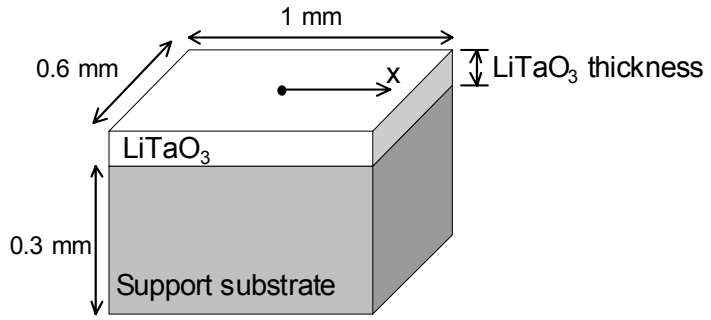

Fig. 1. FEM simulation model.

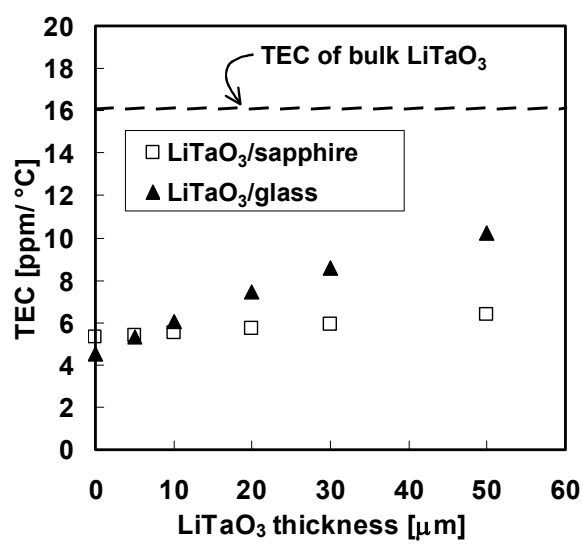

Fig. 2. FEM simulation results for the TECs of the bonded substrates at the center of the $\mathrm{LiTaO}_{3}$ surface.

Table 1. Properties of candidate materials for a support substrate and of $\mathrm{LiTaO}_{3}$ (Thermal expansion coefficient and Young's modulus of Glass are taken from ref. (4) The listed Thermal expansion coefficient of $\mathrm{LiTaO}_{3}$ is the value in the SAW propagation direction.).

\begin{tabular}{|c|c|c|c|}
\hline Material & $\begin{array}{c}\text { Thermal expansion } \\
\text { coefficient } \\
{[\mathrm{ppm} / \mathrm{K}]}\end{array}$ & $\begin{array}{c}\text { Young's modulus } \\
{[\mathrm{GPa}]}\end{array}$ & $\begin{array}{c}\text { Thermal } \\
\text { conductivity } \\
{[\mathrm{W} / \mathrm{m} / \mathrm{K}]}\end{array}$ \\
\hline Glass & 4.5 & 66 & 1 \\
\hline Sapphire & 5 & 470 & 42 \\
\hline Silicon & 3 & 160 & 160 \\
\hline $\mathrm{LiTaO}_{3}$ & 16.1 & 230 & 2 \\
\hline
\end{tabular}

SAW を励振すると, 圧電基板と支持基板の音響インピーダ ンスの不連続によりバルク波が接合界面で反射し, IDT に再 入射することでスプリアス応答を生じる。図 3 に断面模式 図を, 図 4 に単体共振器の周波数特性を示す。スプリアス 応答は反共振周波数より高周波の領域に主に発生する。良 好な周波数特性を持つフィルタを実現するには，スプリア ス応答をできるだけ抑える必要がある。US-PCS デュープレ クサ用フィルタの場合, 送信 $(\mathrm{Tx})$ フィルタの受信帯域に 発生するスプリアスを抑圧することが求められる。検討を 行った結果, $\mathrm{LiTaO}_{3}$ 厚とスプリアスの振幅の間に相関があ ることを見出した。結果を図 5 に示す。 $\mathrm{LiTaO}_{3}$ 厚が厚くな ると共に急速にスプリアス応答が減衰することが分かる。 $\mathrm{LiTaO}_{3}$ 厚が $10 \lambda$ 以上では $2 \mathrm{~dB}$ 程度以下と, US-PCS デュー プレクサ用として実用上問題ないレベルとなっている。 


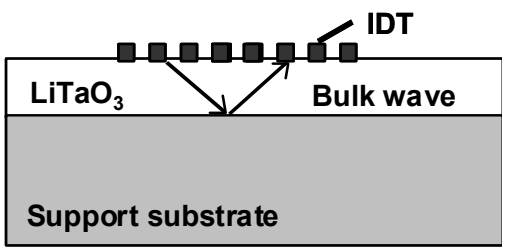

Fig. 3. Schematic of a bulk wave reflecting at the bonding interface

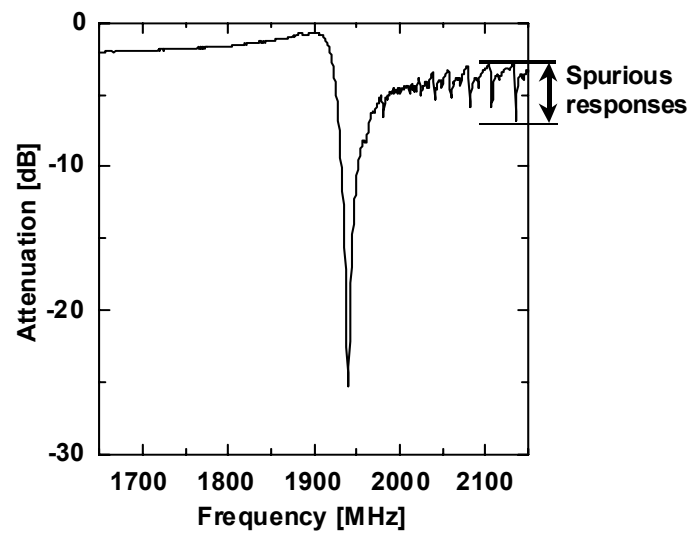

Fig. 4. Frequency characteristics, including spurious responses, of a one-port SAW resonator using a bonded $\mathrm{LiTaO}_{3} /$ sapphire.

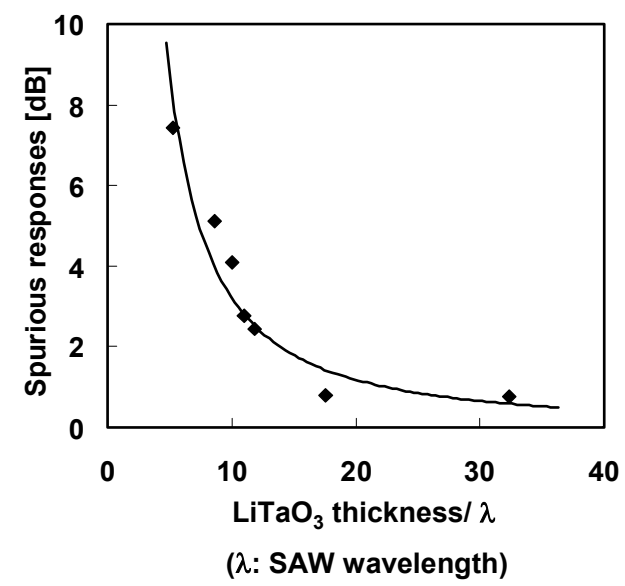

Fig. 5. Amplitude of the spurious responses as a function of the ratio of the $\mathrm{LiTaO}_{3}$ thickness to the $\mathrm{SAW}$ wavelength.

\section{3. 共振器特性}

42Y-X $\mathrm{LiTaO}_{3}$ /サファイア接合基板を用いて共振器を作製 した。 $\mathrm{LiTaO}_{3}$ 基板の厚さは $37 \mu \mathrm{m}$ （約 $18 \lambda$ ）, サファイア基 板の厚さは $250 \mu \mathrm{m}$ である。周波数特性を図 6 に示す。42Y-X $\mathrm{LiTaO}_{3}$ 基板上に作製した共振器の特性と比較しているが, 接合基板上の共振器でもスプリアス応答が抑制されてい る。また, サファイアの比誘電率が約 10 と小さいため, 従 来の $\mathrm{LiTaO}_{3}$ 基板と比較すると対接地容量が約 4 割低減され ている。そのため，共振周波数より低周波領域および反共 振周波数より高周波領域でロスが低減されている。

周波数温度特性を図 7 に示す。 $\mathrm{LiTaO}_{3}$ /サファイア接合基

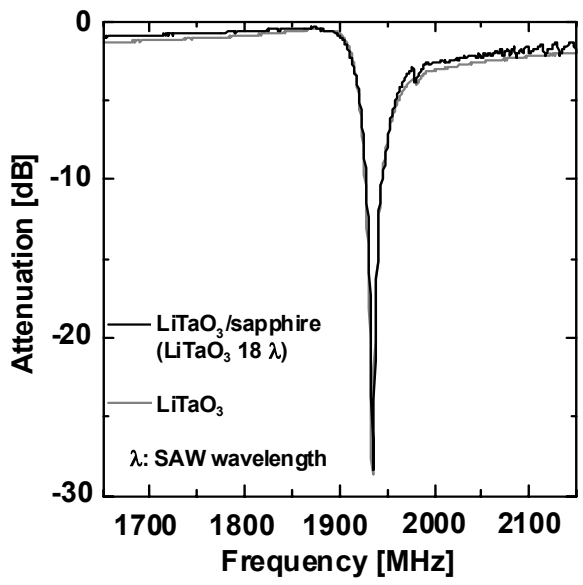

Fig. 6. Frequency characteristics of one-port SAW resonators using a bonded $\mathrm{LiTaO}_{3} /$ sapphire substrate and a conventional $\mathrm{LiTaO}_{3}$ substrate.

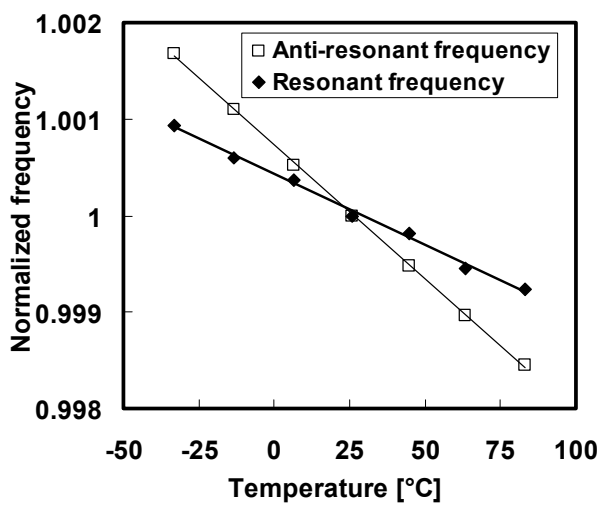

Fig. 7. Temperature characteristics of the resonant and anti-resonant frequencies of a one-port SAW resonator using a bonded $\mathrm{LiTaO}_{3} /$ sapphire substrate.

板上での共振周波数の TCF (Temperature Coefficient of Frequency) は- $15 \mathrm{ppm} /{ }^{\circ} \mathrm{C}$, 反共振周波数の TCF は- $27 \mathrm{ppm} /{ }^{\circ} \mathrm{C}$ という值が得られている。通常の $\mathrm{LiTaO}_{3}$ 基板上の $\mathrm{SAW} の$ $\mathrm{TCF}$ 值（共振 : $-30 \mathrm{ppm} /{ }^{\circ} \mathrm{C}$, 反共振 : $-40 \mathrm{ppm} /{ }^{\circ} \mathrm{C}$ ) と比較 すると, それぞれ約 $1 / 2,2 / 3$ の值となっており, 大幅に改 善されていることが分かる。

\section{US-PCS デュープレクサへの適用}

〈4・1〉 周波数特性 $\mathrm{LiTaO}_{3} /$ サファイア接合基板を用 いて US-PCS デュープレクサを作製した。 $\mathrm{LiTaO}_{3}$ 基板の厚さ は $40 \mu \mathrm{m}$ (約 $20 \lambda$ ), サファイア基板の厚さは $250 \mu \mathrm{m}$ である。 前述したように, 従来の $\mathrm{LiTaO}_{3}$ 基板とは基板の対接地容量 が異なるため, フィルタ設計は $\mathrm{LiTaO}_{3} /$ サファイア接合基板用 に最適化されており, 送信 $(\mathrm{Tx})$, 受信 $(\mathrm{Rx})$ フィルタを $3 \times 3 \mathrm{~mm}^{2}$ のセラミックパッケージに搭載し, パッケージ内部で接続し ている。通過特性を図 8 に示す。従来の $\mathrm{LiTaO}_{3}$ 基板を用い て作製した $5 \times 5 \mathrm{~mm}^{2}$ の US-PCS デュープレクサと比較して いる。従来の $\mathrm{LiTaO}_{3}$ 基板では, $\mathrm{Tx}$ フィルタのロスが $2.3 \mathrm{~dB}$, $\mathrm{Rx}$ フィルタのロスが $3.5 \mathrm{~dB}$ に対して, $\mathrm{LiTaO}_{3} /$ サファイア接 


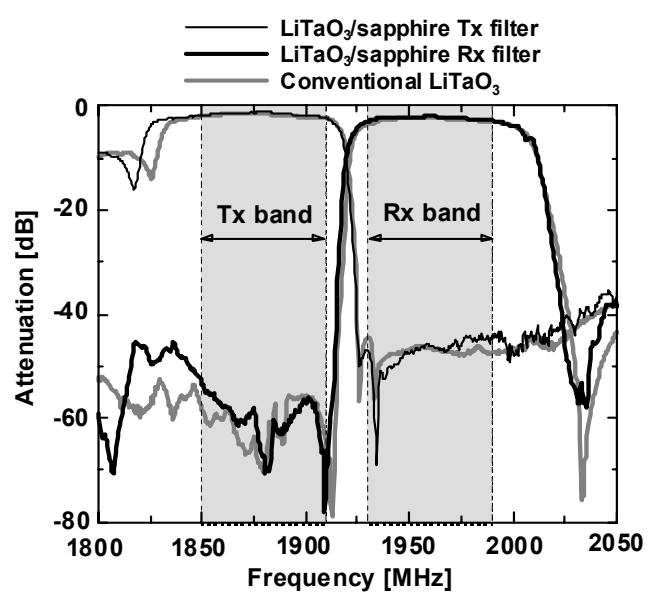

Fig. 8. Frequency characteristics of US-PCS SAW duplexers using a bonded $\mathrm{LiTaO}_{3} /$ sapphire substrate and a conventional $\mathrm{LiTaO}_{3}$ substrate.

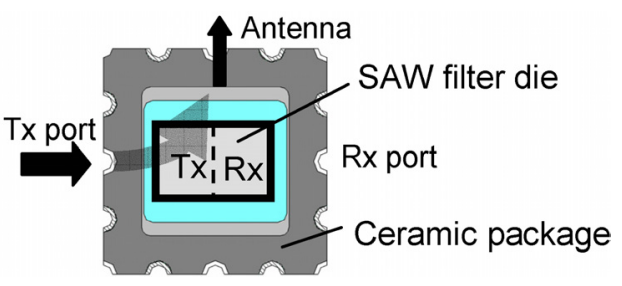

(a) Device configuration

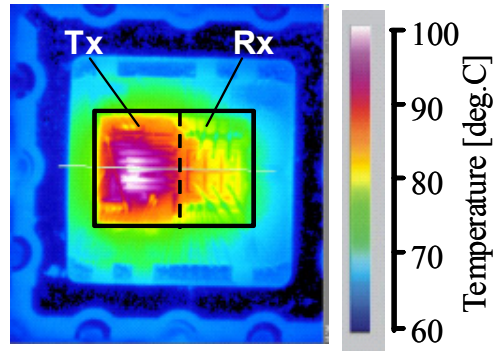

(b) $\mathrm{LiTaO} 3$ substrate

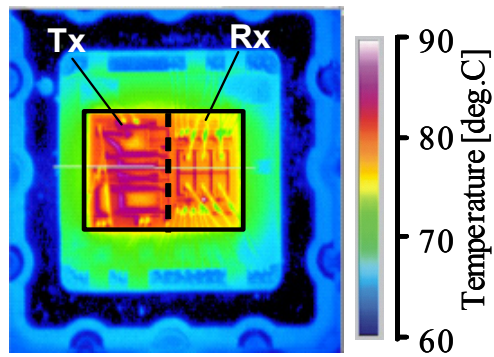

(c) $\mathrm{LiTaO}_{3} /$ sapphire substrate.

Fig. 9. Thermal image of SAW filter die when $0.8 \mathrm{~W}$ of power was applied.

合基板では， $\mathrm{Tx}$ フィルタのロスが $2.3 \mathrm{~dB}, \mathrm{Rx}$ フィルタのロ スが $2.9 \mathrm{~dB}$ と同等以上のロス特性を実現している。

〈4·2〉 高耐電力性 $\quad \mathrm{LiTaO}_{3} /$ サファイア接合基板での 高耐電力性を確認するため, 赤外線センサによる SAW フィ ルタダイ温度の測定を行った。図 9(a)に示す構成により, 周 辺温度 $60{ }^{\circ} \mathrm{C}$ 環境においてパッケージの $\mathrm{Tx}$ ポートから

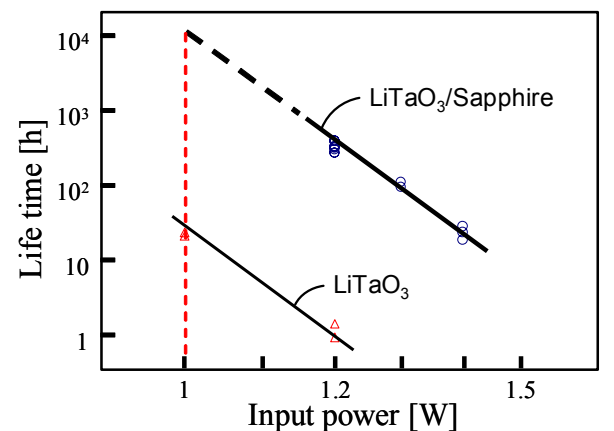

Fig. 10. Life time of $3 \times 3 \mathrm{~mm}^{2}$ US-PCS SAW duplexers using a bonded $\mathrm{LiTaO}_{3} /$ sapphire substrate and a conventional $\mathrm{LiTaO}_{3}$ substrate.

$0.8 \mathrm{~W}$ の電力を印加した。(b)に示した従来の $\mathrm{LiTaO}_{3}$ 基板を 用いた SAW フィルタダイでは，Tx フィルタの IDT 部分が 局所的に約 $100{ }^{\circ} \mathrm{C}$ ま゙温度上昇していることが分かる。そ れに対して, (c)に示した $\mathrm{LiTaO}_{3}$ /サファイア接合基板を用い た SAW フィルタダイでは熱集中の度合いが弱くなってお り, 最高温度も $90{ }^{\circ} \mathrm{C}$ 未満と従来の $\mathrm{LiTaO}_{3}$ 基板を用いた $\mathrm{SAW}$ フィルタダイよりも $10{ }^{\circ} \mathrm{C}$ 以上低くなっている。これ は, $\mathrm{LiTaO}_{3}(2 \mathrm{~W} / \mathrm{m} / \mathrm{K})$ とサファイア $(42 \mathrm{~W} / \mathrm{m} / \mathrm{K})$ の熱伝導 率の違いによるものであり, $\mathrm{LiTaO}_{3}$ /サファイア接合基板を 用いたものでは，より効率的に排熱ができていることを示 している。デバイスの温度上昇軽減が IDT の $\mathrm{Al}$ 電極のマイ グレーションを抑制し，耐電力性を改善すると考えられる。 図 10 に周辺温度 $85{ }^{\circ} \mathrm{C}$ での $3 \times 3 \mathrm{~mm}^{2}$ の US-PCS デュープレ クサの耐電力特性を示す。 $\mathrm{LiTaO}_{3}$ /サファイア接合基板を用 いたものでは, 従来の $\mathrm{LiTaO}_{3}$ 基板を用いた場合と比べて, 寿命が 100 倍以上に改善されていることが分かる。

$\mathrm{LiTaO}_{3} /$ サファイア接合基板では, デバイスの $\mathrm{TCF}$ が改善 されているだけでなく, チップのジュール熱を効率的に排 熱することによって, デバイス自体の温度上昇を軽減する という 2 重の作用によって温度特性を改善できていること が分かる。

\section{5. まとめ}

$\mathrm{LiTaO}_{3}$ /サファイア接合基板を用いて $\mathrm{SAW}$ フィルタの温 度特性の改善を行った。接合基板では不可避のスプリアス 応答を抑制し， $3 \times 3 \mathrm{~mm}^{2}$ の超小型 US-PCS デュープレクサ を実現した。TCF の改善ばかりでなく, 効率的な排熱によ るデバイスの温度上昇軽減も温度特性の改善に貢献し, 同 時に耐電力性も向上できた。

(平成 18 年 11 月 22 日受付, 平成 19 年 2 月 27 日再受付)

\section{文献}

(1) T. Matsuda, J. Tsutsumi, S. Inoue, Y. Iwamoto, Y. Satoh, M. Ueda, and O. Ikata : "High-Frequency SAW Duplexer with Low-Loss and Steep Cut-Off Characteristics", Proc. of IEEE Ultrasonics Sympo., pp.68-73 (2002)

(2) K. Yamanouchi and S. Hayama : "SAW Properties of $\mathrm{SiO}_{2} / 128^{\circ} \mathrm{Y}-\mathrm{X}$ $\mathrm{LiNbO}_{3}$ Structure Fabricated by Magnetron Sputtering Technique", IEEE. 
Trans. Sonics and Ultrason., Vol.SU-31, pp.51-57 (1984)

( 3 ) M. Kadota, T. Nakao, N. Taniguchi, E. Takata, M. Miura, K. Nishiyama, T. Hada, and T. Komura : "SAW Substrate with Coupling Factor and Excellent Temperature Stability suitable for Duplexer of PCS in US", Proc. IEEE. Ultrasonics Sympo., pp.1970-1975 (2004)

(4) K. Onishi, A. Nanba, H. Sato, T. Ogura, S. Seki, Y. Taguchi, M. Tomita, O. Kawasaki, and K. Eda : "A Novel Temperature Compensation Method for SAW Devices Using Direct Bonding Techniques", Proc. IEEE. Ultrasonics Sympo., pp.227-230 (1997)

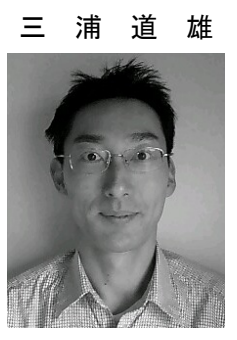

（非会員） 1967 年 11 月 17 日生。1991 年 3 月 東京大学物理工学科卒業。同年, 富士通研究所 入社。以来, 第 2 高調波発生素子, SAW フィ ルタの研究開発に従事。現在, 同社メディアデ バイス研究部所属。応用物理学会会員。

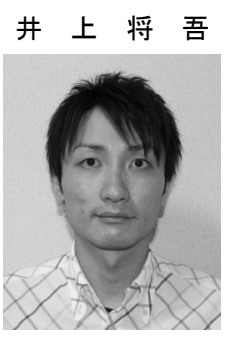

（非会員） 1975 年 9 月 4 日生。2000 年 3 月大 阪大学大学院修士課程修了。同年, 富士通研究 所入社。以来, SAW フィルタの研究開発に従 事。現在，同社メディアデバイス研究部所属。

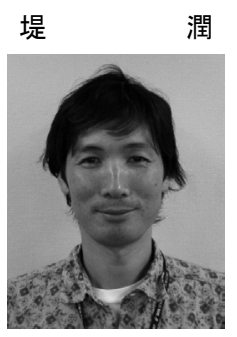

（非会員） 1969 年 9 月 2 日生。1 994 年 3 月大 阪大学大学院修士課程修了。同年, 富士通研究 所入社。以来, SAW フィルタ, FBARフィルタ の研究開発に従事。現在, 同社メディアデバイ ス研究部所属。電子情報通信学会会員。工学博 士。

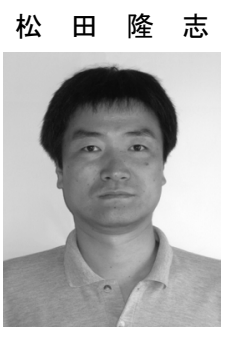

（非会員） 1964 年 9 月 21 日生。 1989 年 3 月室 蘭工業大学大学院修士課程修了。同年富士通研 究所入社。以来, SAW フィルタの研究開発に 従事。現在，同社メディアデバイス研究部主任 研究員。電子情報通信学会会員。

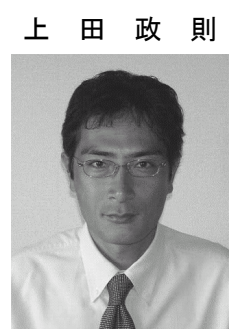

(非会員) 1963 年 8 月 30 日生。1988 年 3 月室 蘭工業大学大学院修士課程修了。同年富士通入 社。以来 $\mathrm{SAW}$ フィルタ, FBAR フィルタの研 究開発に従事。02 年より富士通研究所所属。現 在, 同社メディアデバイス研究部主任研究員。 電子情報通信学会会員。

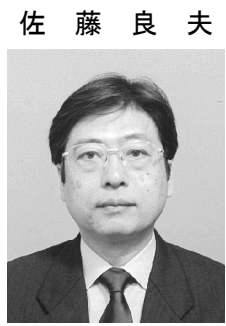

（正員） 1949 年 10 月 4 日生。1974 年 3 月東 北大学大学院修士課程修了。同年富士通研究所 入社。以来バブルメモリー, SAW フィルタの 研究開発に従事。現在, 同社フェロー。電子情 報通信学会会員。工学博士。

伊 形

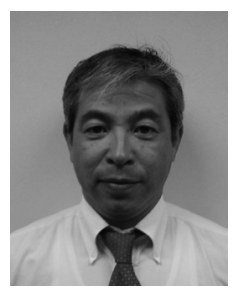

（非会員） 1960 年 9 月 20 日生。 1985 年 3 月日 本大学大学院修士課程修了。同年富士通研究所 入社。以来，バブルメモリー，SAW フィルタ の研究開発に従事。01 年より富士通メディアデ バイス(株)所属。現在, 同社通信デバイス事業 部長代理。電子情報通信学会, 応用磁気学会会 員。

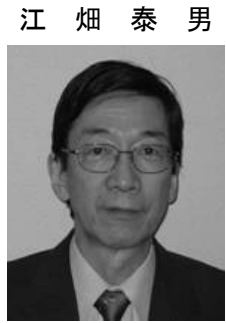

（非会員） 1948 年 6 月 24 日生。 1971 年 3 月横 浜国立大学電気工学科卒業。同年東芝総合研究 所入社。以来, SAW デバイスの研究開発に従 事。04 年富士通メディアデバイス (株) に転籍。 現在，同社専任部長。電子情報通信学会会員。 工学博士。 